\title{
A New Route for Ethylene Glycol Metabolism in Mycobacterium E44
}

\author{
By WIM M. WIEGANT AND JAN A. M. DE BONT* \\ Laboratory of Microbiology, Hesselink van Suchtelenweg 4, Wageningen, \\ The Netherlands
}

(Received 6 November 1979; revised 12 May 1980)

\begin{abstract}
A Mycobacterium sp. which grows on ethylene and ethylene glycol was isolated from ditch water. Growth of the organism, respiration of washed organisms, experiments on excretion of metabolic intermediates and enzyme studies were consistent with a new route for the degradation of ethylene glycol via acetaldehyde and acetate. Cell-free extracts of organisms grown on ethylene glycol contained a diol dehydratase which required $\mathrm{K}^{+}$ or $\mathrm{NH}_{4}{ }^{+}$for activity as well as coenzyme $\mathrm{B}_{12}$ (5'-deoxyadenosyl cobalamin). Ethylene glycol was not an intermediate in ethylene metabolism.
\end{abstract}

\section{INTRODUCTION}

The metabolism of ethylene in Mycobacterium E20 involves the epoxidation of the double bond by a mono-oxygenase (de Bont et al., 1979). The product, ethylene oxide, is converted to acetyl-CoA in a reaction requiring $\mathrm{NAD}^{+}, \mathrm{CoA}$ and an unknown cofactor (de Bont \& Harder, 1978). Ring opening of ethylene oxide with water to form ethylene glycol might be a plausible alternative to this reaction because enzymic diol formation from an epoxide is a common reaction (Jakoby \& Fjellstedt, 1972). Growth of an organism on ethylene and ethylene glycol could indicate the existence of this alternative route of degradation, but previously such an organism has not been isolated (de Bont, 1976; S. B. Primrose, personal communication). The recent isolation of an ethylene-utilizing bacterium, Mycobacterium E44, able to grow on ethylene glycol, prompted us to investigate the metabolism of ethylene glycol and its possible role in ethylene metabolism.

\section{METHODS}

Organism, media ind culture conditions. A Gram-positive pleomorphic bacterium classified as $M y c o-$ bacterium E44 (de Bont et al., 1980) was isolated from ditch water using ethylene as the sole carbon and energy source by a method described previously (de Bont, 1976). The organism was maintained on a medium containing ( $\mathrm{g} \mathrm{l}^{-1}$ in tap water): glucose, 10; yeast extract, 7; and Oxoid no. 3 agar, 12. The growth medium contained ( $\mathrm{g} \mathrm{l}^{-1}$ in deionized water): $\mathrm{K}_{2} \mathrm{HPO}_{4}, 1 \cdot 55 ; \mathrm{NaH}_{2} \mathrm{PO}_{4}, 0 \cdot 85 ; \mathrm{NH}_{4} \mathrm{Cl}, 2 \cdot 0 ; \mathrm{MgCl}_{2} .6 \mathrm{H}_{2} \mathrm{O}, 0.075$; $\left(\mathrm{NH}_{4}\right)_{2} \mathrm{SO}_{4}, 0 \cdot 1$; yeast extract, $0 \cdot 1$; and $0 \cdot 2 \mathrm{ml}$ of a trace element solution as described by Vishniac \& Santer (1957). Carbon sources were added to give final concentrations of $1 \mathrm{~g} \mathrm{t}^{-1}$. Cultures $(500 \mathrm{ml}$ medium in 51 Erlenmeyer flasks) were inoculated with $100 \mathrm{ml}$ inoculum cultures grown in the same medium. The cultures were incubated at $30^{\circ} \mathrm{C}$ with shaking at $1 \mathrm{~Hz}$. For growth on ethylene, the flasks were sealed with rubber stoppers fitted with Suba-seals through which $200 \mathrm{ml}$ ethylene was injected.

Chemical estimations. Acetaldehyde and propionaldehyde were determined with a Becker 417 gas chromatograph fitted with a Porapak R column; the column temperature was $180^{\circ} \mathrm{C}$ and the carrier gas was $\mathrm{N}_{2}$. Acetic acid and ethylene glycol were measured with a Varian Aerograph series 2400 gas chromatograph fitted with a Chromosorb 101 ( 80 to 100 mesh) column; the column temperature was $190^{\circ} \mathrm{C}$ and the carrier gas was $\mathrm{N}_{2}$ saturated with formic acid. 
Dissolved $\mathrm{O}_{2}$ concentrations were measured at $30^{\circ} \mathrm{C}$ with a Yellow Springs Instrument Co. model 53 monitor equipped with a polarographic sensor.

Protein was measured by the Lowry method, with bovine serum albumin as the standard.

Respiration measurements and determination of excretion products. Organisms were harvested by centrifugation at $16000 \mathrm{~g}$ for $20 \mathrm{~min}$ at $4{ }^{\circ} \mathrm{C}$, washed with $50 \mathrm{mM}-\mathrm{KH}_{2} \mathrm{PO}_{4} / \mathrm{K}_{2} \mathrm{HPO}_{4}$ buffer, $\mathrm{pH} 7 \cdot 2$ and resuspended in the same buffer.

Endogenous oxygen uptake by $10 \mathrm{ml}$ washed cell suspensions was measured for at least $5 \mathrm{~min}$ at $30^{\circ} \mathrm{C}$. Subsequently, $0.1 \mathrm{ml}$ of substrate solutions $\left(5 \mathrm{~g} \mathrm{l}^{-1}\right)$, or $0.1 \mathrm{ml}$ of water in equilibrium with an ethylene gas-phase, was added and oxygen uptake was followed for at least $4 \mathrm{~min}$.

Excretion of metabolic intermediates by washed cell suspensions ( $10 \mathrm{ml}$ final volume) was measured in screw-cap bottles $(40 \mathrm{ml})$ that were incubated at $30^{\circ} \mathrm{C}$ in a shaking water bath. Acetaldehyde production was followed by taking samples $(0.2 \mathrm{ml})$ from the gas-phase for analysis. Breakdown of ethylene glycol in incubation mixtures was stopped at different times by injecting $1 \mathrm{ml}$ formic acid, and ethylene glycol and acetic acid were measured in the supernatant fluid after centrifugation at $27000 \mathrm{~g}$ for $10 \mathrm{~min}$ at $4{ }^{\circ} \mathrm{C}$.

Enzyme assays. Cell-free extracts were obtained by ultrasonic disintegration with a Branson B-12 sonifier $\left(6 \times 30 \mathrm{~s}, 0^{\circ} \mathrm{C}\right)$ of the washed cells in $50 \mathrm{~mm}-\mathrm{KH}_{2} \mathrm{PO}_{4} / \mathrm{K}_{2} \mathrm{HPO}_{4}$ buffer, $\mathrm{pH} 7.2$ containing $1 \mathrm{~mm}$-dithiothreitol and $2 \mathrm{mM}-\mathrm{MgCl}_{2}$. All subsequent procedures with the extract were carried out in the dark. The resulting suspension was centrifuged at $27000 \mathrm{~g}$ for $20 \mathrm{~min}$ at $4{ }^{\circ} \mathrm{C}$ and the supernatant, containing 5 to $10 \mathrm{mg}$ protein $\mathrm{ml}^{-1}$, was used for the enzyme assays. Gel filtration of the extract used in the experiments shown in Fig. 2(b) was performed by passing $1 \mathrm{ml}$ of the extract down a $25 \mathrm{ml}$ Sephadex G-25 column, eluting with $50 \mathrm{~mm}$-Tris/ $\mathrm{HCl}$ buffer, $\mathrm{pH} 7.8$ containing $1 \mathrm{~mm}$-dithiothreitol.

The following enzymes were assayed as previously described: $\mathrm{NAD}^{+}$-dependent isocitrate dehydrogenase

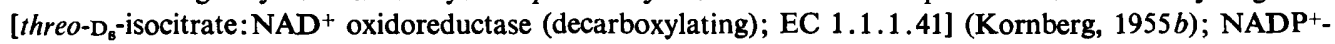
dependent isocitrate dehydrogenase $\left[\right.$ threo- $\mathrm{D}_{\mathrm{g}}$-isocitrate: $\mathrm{NADP}^{+}$oxidoreductase (decarboxylating); EC 1.1.1.42] (Kornberg, 1955a); $\mathrm{NAD}^{+}$-dependent acetaldehyde dehydrogenase [aldehyde: $\mathrm{NAD}^{+}$oxidoreductase; EC 1.2.1.3] (Racker, 1955); isocitrate lyase [threo- $\mathrm{D}_{\mathrm{g}}$-isocitrate glyoxylate-lyase; EC 4.1.3.1] (Dixon \& Kornberg, 1959); malate synthase [L-malate glyoxylate-lyase (CoA-acetylating); EC 4.1.3.2] (Dixon \& Kornberg, 1962). Citrate synthase [citrate oxaloacetate-lyase (CoA-acetylating); EC 4.1.3.7] was assayed using the malate synthase method and replacing glyoxylate with oxaloacetate. $\mathrm{NAD}^{+-}$and CoA-dependent oxidation of ethylene oxide was assayed according to de Bont \& Harder (1978).

Acetothiokinase [acetate:CoA ligase (AMP-forming); EC 6.2.1.1] was measured in a coupled assay with citrate synthase [citrate oxaloacetate-lyase (CoA-acetylating); EC 4.1.3.7] and malate dehydrogenase [L-malate: $\mathrm{NAD}^{+}$oxidoreductase; EC 1.1.1.37]. The final mixture contained, in $1.0 \mathrm{ml}, 50 \mu \mathrm{mol}$ Tris/ $\mathrm{HCl}$, pH $8 \cdot 0,0 \cdot 1 \mathrm{ml}$ extract, $10 \mu \mathrm{mol}$ malate, $5 \mu \mathrm{mol} \mathrm{ATP,} 0.5 \mu \mathrm{mol} \mathrm{CoA}, 20 \mu \mathrm{mol}$ acetate, $3 \mu \mathrm{mol} \mathrm{NAD}^{+}$, $0.04 \mathrm{mg}$ malate dehydrogenase and $1 \mathrm{mg}$ citrate synthase. The reaction was started by the addition of CoA, ATP or acetate and the change in $A_{340}$ due to $\mathrm{NAD}^{+}$reduction was followed continuously with a Beckman model 25 spectrophotometer. The reaction mixture in the reference curvette lacked CoA, ATP or acetate. A lag period of several minutes preceded a linear rate of NADH formation. Under these conditions a change of 6.22 absorbance units was taken to correspond to the formation of $1 \mu \mathrm{mol}$ acetyl-CoA per cuvette.

Diol dehydratase in crude extracts was assayed by following aldehyde production. Vacutainer tubes (13.0 ml; Becton-Dickinson, France) containing $0.8 \mathrm{ml} 50 \mathrm{~mm}-\mathrm{KH}_{2} \mathrm{PO}_{4} / \mathrm{K}_{2} \mathrm{HPO}_{4}$ buffer, $\mathrm{pH} 7.2$ and $0.1 \mathrm{ml}$ 100 mM-ethylene glycol or propylene glycol were stoppered and flushed with $\mathrm{N}_{2}$ for $20 \mathrm{~s}$ at a rate of $10 \mathrm{ml}$ $\mathrm{s}^{-1}$. Tubes were wrapped in aluminium foil and incubated at an angle of $45^{\circ}$ at $30^{\circ} \mathrm{C}$ with shaking at 2.7 $\mathrm{Hz}$. The reaction was started by injecting $0.1 \mathrm{ml}$ of crude extract. When gel-filtered extract was used the assay mixture contained, in $1.0 \mathrm{ml}, 30 \mu \mathrm{mol}$ Tris/ $\mathrm{HCl}, \mathrm{pH} 7.8,40 \mu \mathrm{mol} \mathrm{KCl}, 24 \mathrm{nmol} 5$ '-deoxyadenosyl cobalamin (DBC), and $10 \mu \mathrm{mol}$ ethylene glycol or propylene glycol. The reaction was followed by periodically analysing $0.2 \mathrm{ml}$ samples for acetaldehyde production in the gas-phase by gas chromatography. Aldehyde in the gas-phase was not readily in equilibrium with aldehyde in solution. Under the conditions employed, it took about $5 \mathrm{~min}$ to reach complete equilibrium between the two phases.

Chemicals. $\mathrm{NAD}^{+}$, NADP ${ }^{+}$, ATP, AMP, malate dehydrogenase and citrate synthase were obtained from Boehringer. 5'-Deoxyadenosyl cobalamin (DBC) and hydroxocobalamin hydrochloride (vitamin $\mathbf{B}_{12 \mathrm{~b}}$ ) were obtained from BDH.

\section{RESULTS}

\section{Growth characteristics of Mycobacterium E44}

Mycobacterium E44 grew on ethylene, ethylene glycol and succinate, with culture doubling times of $18,8.5$ and $9.5 \mathrm{~h}$, respectively, and on ethanolamine and glucose as sole carbon and energy sources. Ethane, propylene, ethanol, glycollate and glyoxylate did not support growth. 
Table 1. Rates of substrate-dependent oxygen uptake by washed cell suspensions of Mycobacterium E44

\begin{tabular}{|c|c|c|c|}
\hline \multirow[b]{2}{*}{ Assay substrate } & \multicolumn{3}{|c|}{ Rate of oxygen uptake } \\
\hline & Ethylene glycol & $\begin{array}{c}\text { Growth substrate: } \\
\text { Ethylene }\end{array}$ & Succinate \\
\hline Ethylene & 0 & 450 & 0 \\
\hline Ethylene oxide & 0 & 175 & 0 \\
\hline Ethanol & 25 & 50 & $\mathbf{0}$ \\
\hline Ethylene glycol & 200 & 25 & 50 \\
\hline Acetaldehyde & 275 & 150 & 150 \\
\hline Acetate & 500 & 100 & 75 \\
\hline Glycolaldehyde & 575 & 50 & 50 \\
\hline Glycollate & 100 & 25 & 50 \\
\hline Glyoxylate & 75 & ND & 75 \\
\hline Succinate & 25 & 100 & 150 \\
\hline
\end{tabular}

\section{Simultaneous adaptation studies}

Substrate-dependent oxygen uptake by washed cell suspensions was determined for bacteria grown on ethylene, ethylene glycol or succinate (Table 1). Ethylene glycol did not significantly stimulate oxygen uptake by ethylene-grown cells, indicating that it was not an intermediate in the metabolism of ethylene. Furthermore, acetaldehyde and acetate greatly increased oxygen uptake by cells grown on ethylene glycol. This suggested that acetaldehyde and acetate were intermediates in ethylene glycol metabolism. The pattern of ethylene oxide stimulation of oxygen uptake suggested that this compound was an intermediate in ethylene metabolism.

\section{Excretion of intermediate metabolites during ethylene glycol catabolism}

The transient accumulation of acetaldehyde from ethylene glycol was detected using suspensions of washed organism grown on ethylene glycol (Fig. 1a). Under these conditions acetate was not detected but it accumulated as a result of ethylene glycol catabolism in the presence of 20 mM-fluoroacetate (Fig. $1 b$ ).

\section{Activities of enzymes in cell-free extracts}

The results described above suggest that acetaldehyde and acetate are intermediates in the metabolism of ethylene glycol by Mycobacterium E44. Additional evidence for this suggestion was obtained by estimating activities of the relevant enzymes in extracts of Mycobacterium E44 grown on ethylene glycol or succinate. Acetaldehyde dehydrogenase and acetothiokinase activities were higher in extracts of ethylene glycol-grown organisms than in extracts of succinate-grown organisms (Table 2). The aldehyde dehydrogenase was not specific for acetaldehyde because propionaldehyde and, particularly, glycolaldehyde were good substrates for this enzyme as well.

Extracts were also assayed for enzymes of the glyoxylate cycle. The specific activity of isocitrate lyase in ethylene glycol-grown organisms was much higher than in succinategrown organisms, whereas the specific activities of malate synthase were similar. As expected, the specific activities of citrate synthase and isocitrate dehydrogenase were similar in both extracts.

Oxidation of ethylene oxide occurred in extracts of ethylene-grown organisms when 

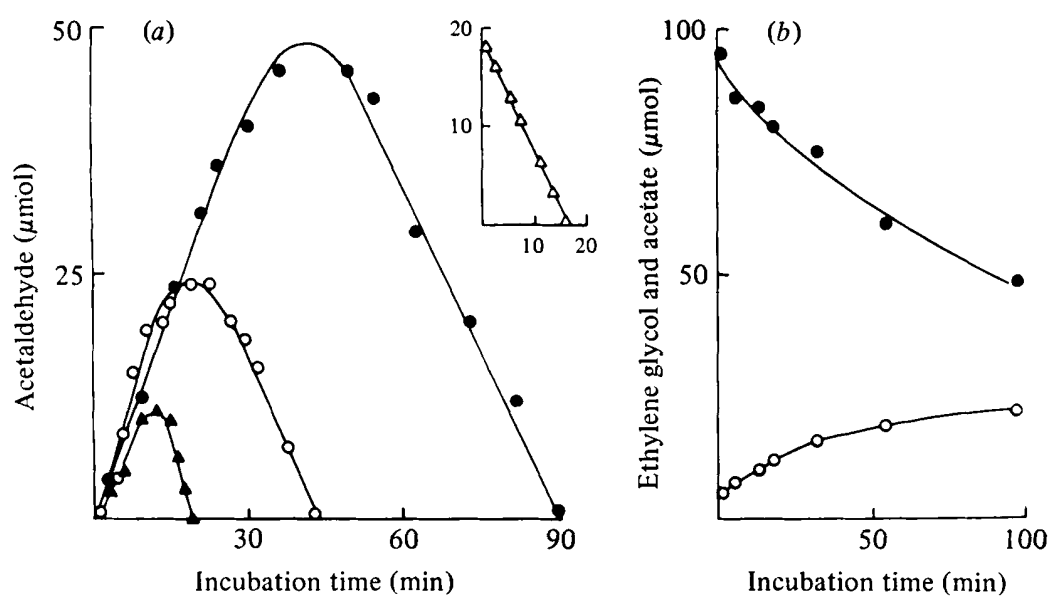

Fig. 1. Formation of acetaldehyde $(a)$ and acetate $(b)$ from ethylene glycol by washed cell suspensions of Mycobacterium E44 grown on ethylene glycol. (a) Suspensions ( $25 \mathrm{mg}$ protein) were incubated with different initial amounts of ethylene glycol $-30 \mu \mathrm{mol}(\boldsymbol{\Delta}), 50 \mu \mathrm{mol}(\bigcirc)$ and $100 \mu \mathrm{mol}(\mathrm{O})$ - and acetaldehyde production was measured as described in Methods. Inset $(\triangle)$ : the incubation mixture contained $20 \mu \mathrm{mol}$ acetaldehyde and no ethylene glycol. (b) Suspensions ( $26 \mathrm{mg}$ protein) were incubated with $100 \mu \mathrm{mol}$ ethylene glycol and $200 \mu \mathrm{mol}$ fluoroacetate and the production of acetate $(O)$ and ethylene glycol remaining (O) were determined as described in Methods.

Table 2. Specific activities of enzymes in cell-free extracts of Mycobacterium E44

Enzyme activity

[nmol substrate converted $\min ^{-1}$ (mg protein) ${ }^{-1}$ ]

\section{Enzyme}

Aldehyde dehydrogenase $\left(\mathrm{NAD}^{+}\right)$

Acetaldehyde

Propionaldehyde

Glycolaldehyde

Acetothiokinase

Isocitrate lyase

Malate synthase

Ethylene oxide dehydrogenase

(NAD+, CoA)

Ethylene glycol dehydratase

Citrate synthase

Isocitrate dehydrogenase ( $\mathrm{NADP}^{+}$)

Isocitrate dehydrogenase (NAD ${ }^{+}$)
Growth substrate:

Ethylene glycol

Ethylene

Succinate

200
160
310
48
19

$\begin{array}{cr}\text { ND } & 10 \\ \text { ND } & \text { ND } \\ \text { ND } & \text { ND } \\ \text { ND } & 9 \\ \text { ND } & 1 \\ \text { ND } & 60 \\ 2 & \text { ND }\end{array}$

$\begin{array}{rrr}90 & 0 & 0 \\ 30 & \text { ND } & 50 \\ 33 & \text { ND } & 25 \\ 0 & \text { ND } & 0\end{array}$

ND, Not determined.

$\mathrm{NAD}^{+}$and $\mathrm{CoA}$ were included in the reaction mixture, but it did not occur in extracts of ethylene glycol-grown organisms (Table 2).

\section{Diol dehydratase activity}

The evidence presented above indicates the possible involvement of a glycol dehydratase (Barker, 1972) in ethylene glycol metabolism. Ethylene glycol-grown organisms contained a diol dehydratase that catalysed the conversion of ethylene glycol to acetaldehyde (Table 2). No diol dehydratase activity was detected in extracts of organisms grown on either ethylene or succinate.

Propylene glycol was also a substrate for the enzyme but ethanolamine was not. The rate of aldehyde production from ethylene glycol or propylene glycol decreased with time 

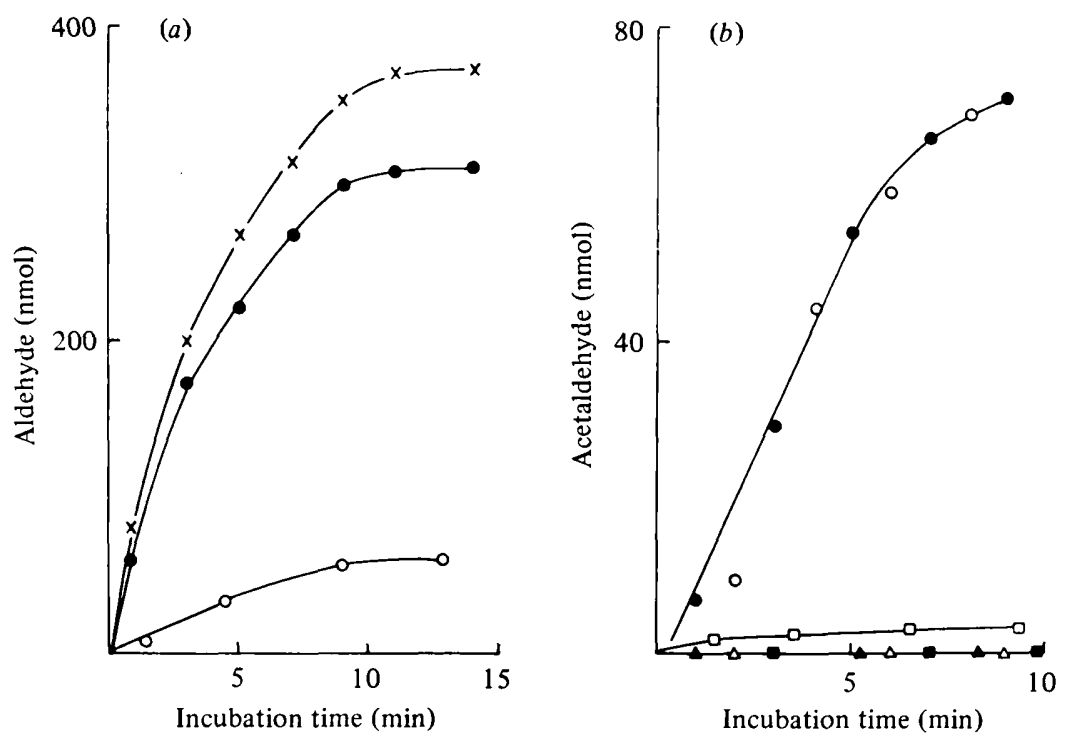

Fig. 2. Aldehyde formation from ethylene glycol and propylene glycol by crude cell-free extract ( $a ; 0.75 \mathrm{mg}$ protein) and extract chromatographed on Sephadex G-25 (b;0.31 mg protein). (a) Reaction mixtures contained: $10 \mu \mathrm{mol}$ ethylene glycol (O); $10 \mu \mathrm{mol}$ propylene glycol $(\mathrm{O})$; ethylene glycol and $24 \mathrm{nmol}$ DBC $(\times)$. (b) Reaction mixtures contained $10 \mu$ mol ethylene glycol

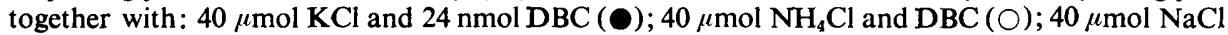
and $\mathrm{DBC}(\square) ; \mathrm{KCl}(\mathbf{\Delta}) ; \mathrm{DBC}(\triangle) ; \mathrm{KCl}$ and $24 \mathrm{nmol}$ vitamin $\mathbf{B}_{12 \mathrm{~b}}(\square)$. (For details, see Methods).

of incubation (Fig. $2 a$ ) at both 30 and $20^{\circ} \mathrm{C}$. Complete loss of activity was observed when the extract was incubated at $30^{\circ} \mathrm{C}$ for $15 \mathrm{~min}$ in the absence of substrate. Although DBC did not stimulate activity of the diol dehydratase in crude extracts, the enzyme was strictly dependent on DBC. This was shown with an extract which had been passed down a Sephadex G-25 column to remove DBC (Fig. $2 b$ ). Vitamin $B_{12 b}$ could not replace DBC. Activity of the enzyme was also dependent on either $\mathrm{K}^{+}$or $\mathrm{NH}_{4}{ }^{+}$but $\mathrm{Na}^{+}$could replace these cations to a limited extent. In crude extracts enzyme activity was completely inhibited by $1 \mathrm{~mm}$-glycolaldehyde. $\mathrm{N}_{2} \mathrm{O}$ and $\mathrm{O}_{2}$, other possible inhibitors of diol dehydratase, did not affect the activity of the enzyme from Mycobacterium E44 when the atmosphere over the assay mixture contained either of these gases. Storing the crude extract for $3 \mathrm{~h}$ on ice in the absence or presence of ethylene glycol under an atmosphere of pure $\mathrm{N}_{2} \mathrm{O}$ or $\mathrm{O}_{2}$ did not affect enzyme activity when compared with an extract that had been stored under $\mathrm{N}_{2}$. Activity or the enzyme under pure $\mathrm{O}_{2}$ was established after correcting for the consumption of acetaldehyde by the extract under these conditions.

\section{DISCUSSION}

On the basis of the results obtained in the present study, we propose a pathway for the metabolism of ethylene glycol and ethylene in Mycobacterium E44, as shown in Fig. 3.

The inability of Mycobacterium E44 to grow on glycollate or glyoxylate and the results of oxygen uptake experiments with washed cell suspensions strongly suggested that, unlike other ethylene glycol-utilizing bacteria studied so far (Stouthamer et al., 1963; Kersters \& de Ley, 1963; Kornberg \& Morris, 1963; Jones \& Watson, 1976; Gonzalez et al., 1972; Child \& Willetts, 1978), glyoxylate was not an intermediate in ethylene glycol metabolism. Strong stimulation by glycolaldehyde of oxygen uptake by suspensions of ethylene glycolgrown organisms (Table 1) was probably due to the broad substrate specificity of the aldehyde dehydrogenase (Table 2). 


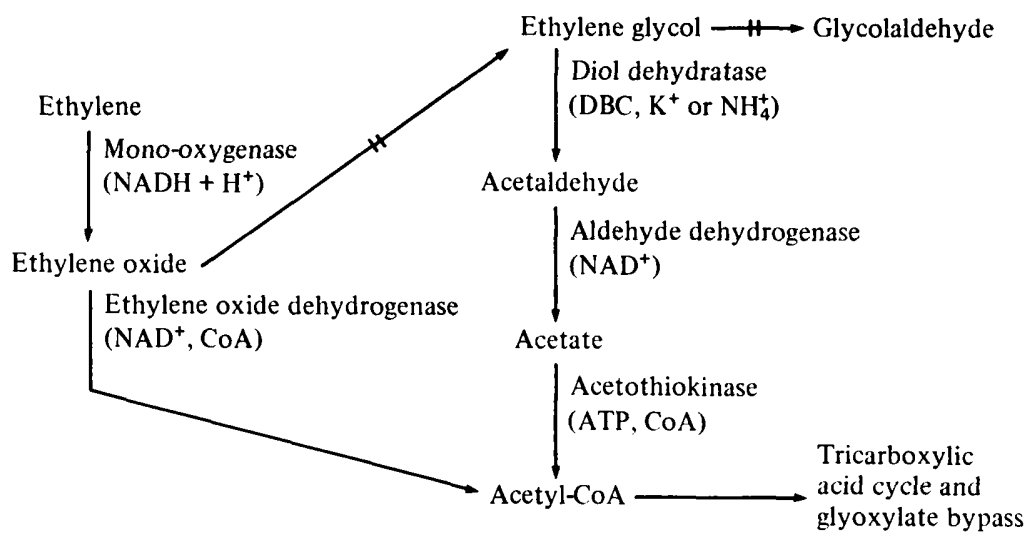

Fig. 3. Proposed pathways for the utilization of ethylene glycol and ethylene in Mycobacterium E44.

For the following reasons we consider that Mycobacterium E44 degrades ethylene glycol via acetaldehyde. Firstly, acetaldehyde was produced from ethylene glycol by suspensions of washed organisms grown on ethylene glycol (Fig. 1a). If it is assumed that acetaldehyde oxidation proceeded at a constant rate during the course of the experiment [ $40 \mathrm{nmol}$ acetaldehyde oxidized $\mathrm{min}^{-1}(\mathrm{mg} \text { protein })^{-1}$ ] an almost stoicheiometric conversion of the diol into the aldehyde at a rate of approximately $95 \mathrm{nmol} \mathrm{min}^{-1}$ (mg protein) ${ }^{-1}$ can be calculated. Secondly, ethylene glycol dehydratase was present in extracts of ethylene glycol-grown Mycobacterium E44 (Table 2), Furthermore, the acetaldehyde produced was oxidized to acetate (Fig. $1 b$, Tables 1 and 2), and acetyl-CoA from acetate was oxidized by the enzymes of the tricarboxylic acid cycle (Table 2). During growth on ethylene glycol the glyoxylate bypass operated since isocitrate lyase was induced. The isocitrate lyase assay method has been criticized because any oxoglutarate formed would also be trapped as a phenylhydrazone (Attwood \& Harder, 1977). However, since the isocitrate dehydrogenase activities in extracts of ethylene glycol- and succinate-grown organisms were similar it can be concluded that an isocitrate lyase activity was measured.

The diol dehydratase acting on ethylene glycol and propylene glycol in Mycobacterium E44 resembles the dehydratases found in Aerobacter aerogenes grown anaerobically on glycerol (Abeles \& Lee, 1961; Lee \& Abeles, 1963; Pawelkiewicz \& Zagalak, 1965) since these enzymes were also coenzyme $\mathrm{B}_{12}$-dependent and required $\mathrm{K}^{+}$or $\mathrm{NH}_{4}{ }^{+}$. The kinetic behaviour of the two enzymes from Aerobacter aerogenes and that from Mycobacterium E44 with respect to ethylene glycol was similar in that a gradual decrease in the reaction rate occurred with time. However, the diol dehydratase from Aerobacter aerogenes converted propylene glycol at a constant rate which was higher than the initial rate of ethylene glycol conversion, whereas for the enzyme from Mycobacterium E44 propylene glycol was a poor substrate compared with ethylene glycol and the rate decreased with time. Inhibition by $\mathrm{N}_{2} \mathrm{O}$ of propionaldehyde formation by diol dehydratase has been observed by Schrauzer et al. (1971), but no inhibition by $\mathrm{N}_{2} \mathrm{O}$ was found in the present investigation. No inhibition by oxygen, as reported by Wagner et al. (1966), was observed, but, as reported by these authors, inhibition by glycolaldehyde was found for the enzyme from Mycobacterium E44.

We would like to thank Dr W. Harder and Dr S. B. Primrose for many invaluable discussions. 


\section{REFERENCES}

Abeles, R. H. \& LeE, H. A. (1961). An intramolecular oxidation-reduction requiring a cobamide coenzyme. Journal of Biological Chemistry 236, 2347-2350.

Attwood, M. M. \& Harder, W. (1977). Isocitrate lyase activity in Hyphomicrobium spp.: a critical reappraisal. FEMS Microbiology Letters 1, 25-30.

BARKer, H. A. (1972). Corrinoid-dependent enzymic reactions. Annual Review of Biochemistry 41, 55-90.

Bont, J. A. M. DE (1976). Oxidation of ethylene by soil bacteria. Antonie van Leeuwenhoek 42, 59-71.

Bont, J. A. M. DE \& Harder, W. (1978). Metabolism of ethylene by Mycobacterium E20. FEMS Microbiology Letters 3, 89-93.

Bont, J. A. M. De, Attwood, M. M., Primrose, S. B. \& HARDER, W. (1979). Epoxidation of short chain alkenes in Mycobacterium E20: the involvement of specific mono-oxygenase. FEMS Microbiology Letters 6, 183-188.

Bont, J. A. M. de, Primrose, S. B., Collins, M. D. \& JoNES, D. (1980). Chemical studies on some bacteria which utilize gaseous unsaturated hydrocarbons. Journal of General Microbiology 117, 97-102.

Child, J. \& Willetts, A. (1978). Microbial metabolism of aliphatic glycols. Bacterial metabolism of ethylene glycol. Biochimica et biophysica acta 538, 316-327.

Dixon, G. H. \& Kornberg, H. L. (1959). Assay methods for key enzymes of the glyoxylate cycle. Biochemical Journal 72, 3P.

Dixon, G. H. \& Kornberg, H. L. (1962). Malate synthase from baker's yeast. Methods in Enzymology 5, 633-637.

Gonzalez, C. F., Taber, W. A. \& Zeitoun, M. A. (1972). Biodegradation of ethylene glycol by a salt-requiring bacterium. Applied Microbiology 24, 911-919.
JAKoBY, W. B. \& FJellstedT, T. A. (1972). Epoxidases. In The Enzymes, 3rd edn, vol. 7, pp. 199212. Edited by P. D. Boyer. New York \& London: Academic Press.

JoNes, N. \& WAtson, G. K. (1976). Ethylene glycol and polyethylene glycol catabolism by a sewage bacterium. Biochemical Society Transactions 4, 891-892.

KeRsters, K. \& Ley, J. DE (1963). The oxidation of glycols by acetic acid bacteria. Biochimica 't biophysica acta 71, 311-331.

KORNBERG, A. (1955a). Isocitric dehydrogenase of yeast (TPN). Methods in Enzymology 1, 705-707.

KORNBERG, A. (1955b). Isocitric dehydrogenase of yeast (DPN). Methods in Enzymology 1, 707-709.

KornberG, H. L. \& Morris, J. G. (1963). $\beta$-Hydroxyaspartate pathway: a new route for biosyntheses from glyoxylate. Nature, London 197, 456-457.

LeE, H. A. \& Abeles, R. H. (1963). Purification and properties of dioldehydrase, an enzyme requiring a cobamide coenzyme. Journal of Biological Chemistry 238, 2367-2373.

Pawelkiewicz, J. \& Zagalak, B. (1965). Enzymic conversion of glycerol into $\beta$-hydroxypropionaldehyde in a cell-free extract from Aerobacter aerogenes. Acta biochimica polonica 12, 207-218.

RACKER, E. (1955). Liver aldehyde dehydrogenase. Methods in Enzymology 1, 514-518.

Schrauzer, G. N., Holland, R. J. \& Seck, J. A. (1971). The mechanisms of coezyme $B_{12}$ action in dioldehydrase. Journal of the American Chemical Society 93, 1503-1505.

Stouthamer, A. H., Boom. J. H. van \& BastiaAnse, A. J. (1963). Metabolism of $\mathrm{C}_{2}$ compounds in Acetobacter aceti. Antonie van Leeuwenhoek 29, 393-406.

Vishniac, W. \& Santer, M. (1957). The thiobacilli. Bacteriological Reviews 21, 195-213.

Wagner, O. W., Lee, A. H., Frey, P. A. \& Abeles, R. H. (1966). Studies on the mechanism of action of cobamide coenzymes. Journal of Biological Chemistry 241, 1751-1762. 